\title{
Induction of Apoptosis by Ethanol Extracts of Fermented Agabeans in AGS Human Gastric Carcinoma Cells
}

Sung Ryeal Kim', Hye Hyeon Lee,2, Min Jeong Kim,2, Min Jeong Seo ${ }^{23}$, Su Hyun Hong4,

Yung Hyun Choi ${ }^{4}$, Byoung Won Kang ${ }^{1,2}$, Jeong Uck Park ${ }^{1,2}$, Woo-Hong Joo ${ }^{5}$, Eun-Ju Rhu ${ }^{6}$ and

Yong Kee Jeong ${ }^{1,23}$ *

${ }^{1}$ Department of Biotechnology, Dong-A University, Busan 604-714, Korea

${ }^{2}$ Medi-Farm Industrialization Research Center, Dong-A University, Busan 604-714, Korea

${ }^{3}$ Department of Medical Bioscience, Dong-A University, Busan 604-714, Republic of South Korea

${ }^{4}$ Department of Bicchemistry, College of Oriental Medicine and Research Institute of Oriental Medicine, Department of Biomaterial Control, Graduate Schod and Blue-Bio Industry Regional Innovation Center, Dongeui University, Busan 614714, Korea

${ }^{5}$ Department of Biology, Changwon National University, Changwon 641-773, Korea

${ }^{6}$ Department of Cosmetology, Han Seo University, Chung Nam 356-706, Korea

Received November 4, 2010 /Accepted December 13, 2010

\begin{abstract}
Extracts of soybeans fermented by Bacillus subtilis have a wide variety of functions, such as enhancing the body's immune function, fibrinolysis activity, anti-inflammation, anti-cancer, estrogen function and anti-infection effects. Recently, it was reported that the extracts of fermented beans exhibit strong anti-inflammatory and anti-cancer properties by suppressing the transcription of pro-inflammatory cytokine genes and induction of apoptosis, respectively. However, the mechanisms of their cytotoxicity in human gastric cancer cells are poorly understood. In the present study, we investigated the effects of ethyl alcohol extracts from fermented soybean (FS) and yellow agabean (FYA) on cell growth and apoptosis in AGS human gastric cancer cells. A treatment of FS and FYA inhibited the growth of AGS cells in a concentration-dependent manner by inducing apoptosis. FS- and FYA-induced apoptosis were associated with down-regulation of XIAP and CIAP-2, and up-regulation of pro-apoptotic Bax expression. Moreover, a treatment of FS and FYA not only triggered an increase in the levels of death receptor (DR)4, DR5, Fas and FasL, but also induced the activation of casepase-3, -8 and -9 . These findings illustrate that FS and FYA may have a therapeutic potential in human gastric AGS cells and as a functional food.
\end{abstract}

Key words : AGS, apoptosis, fermented soybeans

\section{서 론}

세포사멸은 세포의 형태적 및 생화학적 특성에 따라 크게 apoptosis와 necrosis로 구분된다. 이 중 apoptosis는 능동적인 세포사멸 과정으로, 직접적으로 독성이 있거나 물리적 상해 등 갑작스런 외부의 환경에 의해 유발되는 수동적 과정인 necrosis와는 달리 세포의 비중 감소, 세포막의 파괴, 세포질 및 염색질 응축, 세포막 수포화 현상, DNA 단편화 등의 현상이 수반되는 것이 특징이다. 이러한 apoptosis 현상은 세포 내부 에서 신호 전달이 정교하게 이루어지면서 발생 및 조절되어 생체의 발생 및 항상성을 유지하는데 중요한 역할을 하는데, 대부분의 항암효과를 가지는 약물들이 암세포의 apoptosis 유 도에 효과적이란 사실이 알려지면서 apoptosis 유도가 암 치 료법의 하나로 강조되고 있다 $[9,13,24]$.

\footnotetext{
*Corresponding author

Tel : +51-200-7557, Fax : +82-51-206-0848

E-mail : ykj9912@dau.ac.kr
}

위암은 매 년마다 많은 사람들이 진단 받고, 그 만큼의 사람 들이 이 질병으로 인해 사망하고 있다. 특히 중국과 한국을 비롯한 동아시아 국가들은 모든 종류의 암 중에서 위암의 사 망률이 가장 높게 평가되며, 이러한 비율은 점점 더 빠르게 증가되고 있는 실정이다. 현재 위암 치료방법은 큰 효과를 가 지지 못하여 수술 후에도 재발할 가능성이 높으며, 생존율이 낮아 좋은 예후를 기대하기 어렵다. 그래서 새로운 방법으로 치료할 수 있는 연구가 필요한 실정이다 $[16,18,33]$.

한편, 콩은 여러 가지 방법으로 조리되어 섭취되며 그 중 미생물을 이용하여 발효를 시키는 방법에는 한국의 전통 발효 식품인 청국장을 대표적으로 들 수 있다. 고초균(Bacillus subtilis)에 의해 발효되는 청국장은 대두발효 식품 중에서 가장 발효 시간이 짧지만 된장이나 고추장과 같은 다른 대두발효 식품보다 단백질과 지방질 함량이 높고, 발효기간 동안 소금 이 필요 하지 않다는 것이 큰 특징이다. 또한, 발효되는 과정에 서 여러 가지 효소의 작용에 의해 콩에 존재하고 있는 단백질 성분들의 많은 부분이 분해되는데, 이로 인해 혈전용해능 및 
항산화 효과를 가지는 것으로 알려져 있다 $[1,6,12,25]$. 하지만 청국장은 발효 후 끓여서 섭취하는 것이 일방적인 방법이라, 가열하게 되면서 미생물 효소 및 생리활성물질의 파괴가 일어 날 수 있게 되는데, 가까운 일본에서 청국장과 유사한 발효 식품인 "natto"의 경우에는 청국장과 달리 발효시킨 그대로를 섭취함으로써 효소 및 생리활성물질의 파괴를 막을 수 있는 큰 장점이 있다[25].

Natto는 일본의 기능성 전통식품으로 여러 연구를 통해 natto 발효 과정 중 생산되는 단백질 분해효소에 의한 혈전 용해능이 있다는 것이 보고되었다. 또한 소화율이 높고, 식물 성 단백질로서 아미노산, 비타민이 풍부한데, 이 중 비타민 $\mathrm{K}$ 의 생리활성 작용에 의해 혈압 조절 및 당뇨에 효과가 있다 는 연구 결과도 있으며 항산화, 항균 등과 같은 여러 가지 효과 가 보고되었다[11,21,22]. Natto의 원료인 콩의 구성물 중 가장 풍부하게 존재하는 isoflavone은 여성호르몬으로 알려진 estrogen과 유사한 구조를 가지고 있는 phytochemcal로 이러한 isoflavone과 isoflavone이 풍부한 식품은 산화적 손상과 관련 이 있는 유방암과 전립선암 등과 같은 다양한 종류의 암과 동맥경화증 등과 같은 각종 성인병으로부터 예방하는 효과를 가지는 것으로 알려져 있다[2,17,20,26,27]. 최근 경북대학교에 서 품종 육성된 아가콩은 isoflavone의 함량이 다른 콩들에 비해 매우 높은 것으로 확인 되어졌고, 항산화 효과 등 생리활 성 기능이 있는 것을 확인되었다[15,26,27].

본 연구에서는 대두와 아가콩의 발효 추출물의 항암활성 기전을 확인하기 위해 발효된 콩 추출물 처리를 통한 AGS 인체 위암세포의 증식억제가 apoptosis 유발과 밀접한 연관성 이 있음을 확인하였으며, apoptosis 조절에 중요한 몇 가지 유전자 산물의 발현 변화를 조사하였다.

\section{재료 및 방법}

\section{세포배양}

본 연구에 사용된 AGS 인체 위암세포는 한국생명공학연구 소(KRIBB, Taejeon, Korea)에서 분주 받아 사용하였으며, 세포 의 배양을 위해 $90 \%$ 의 RPMI- 1640 배지(Gibco BRL, Grand Island, NY, USA), 10\% fetal bovime serum (FBS, Gibco BRL) 에 $1 \%$ 의 penicillin 및 streptomycin (Gibco BRL)이 포함된 성 장배지를 사용하여 $37^{\circ} \mathrm{C}, 5 \% \mathrm{CO}_{2}$ 조건 하에서 배양하였다.

\section{시료준비 및 처리}

본 실험에 사용된 시료는 시중에서 판매되는 대두 (Soybean)와 경북대학교에서 품종 육성되어진 아가콩 3 호 (Yellow Agabean)를 제공받아 사용하였다. 시료 준비를 위해 각각의 콩을 수세하고 24 시간 동안 침지시킨 뒤 가압증자한 후 실험실에서 따로 분리된 Bacillus sp. sm26 균주 배양액을 증자된 시료의 $3 \%(\mathrm{w} / \mathrm{w})$ 가 되도록 접종하고 $45^{\circ} \mathrm{C}$ 에서 72 시
간 발효하였다. 그 후 제조된 발효물을 $70 \%$ ethanol로 추출하 여 여과한 후 감압 농축하여 각각, 발효 대두 추출물 (Fermented Soybean, FS), 발효 아가콩 3 호 추출물 (Fermented Yellow Agabean, FYA)을 얻어 사용하였다.

\section{$M T$ assay에 의한 세포 성장억제 조사}

FS 및 FYA의 처리에 따른 세포 생존율 비교를 위하여 6 well plate에 AGS 세포를 $1 \times 10^{5}$ 개/ $\mathrm{ml}$ 로 분주하고 FS 및 FYA 를 처리한 후 48 시간 동안 배양 후 배지에 tetrazolium bromide salt (MTT, Amersco, Solon, Ohio, USA) 시약을 0.5 $\mathrm{mg} / \mathrm{ml}$ 농도로 희석하여 분주하여 2 시간 동안 반응시켰다. 반응이 끝난 후 시약을 깨끗하게 제거하고 dimethylsulfoxide (DMSO, Amersco)를 각 well에 동량으로 분주하여 well에 생 성된 formazan을 모두 녹인 후 96 well plate에 200 씨씩 옮겨 서 ELISA reader (Molecular Devices, Sunnyvale, CA, USA) 로 $540 \mathrm{~nm}$ 에서 흡광도를 측정하였다. 측정은 모두 세 번을 하였으며 그에 대한 평균값과 표준오차를 마이크로소프트 엑 셀 프로그램으로 구하였다.

\section{세포의 형태변화 관찰}

$\mathrm{FS}$ 및 FYA 처리에 의한 AGS 세포의 전체적인 변화를 관찰 하기 위하여 세포에 48 시간 동안 농도별로 처리 후 도립현미 경(inverted microscope, Carl Zeiss, Germany)을 이용하여 200 배의 배율로 각 농도에 따른 세포의 형태 변화를 관찰하였 다. 또한 암세포에서 apoptosis 유발 시 특이적으로 나타나는 핵의 형태변화를 관찰하기 위하여 동일 조건으로 처리한 세포 를 모은 다음 37\% formaldehyde 용액과 phosphate buffered saline (PBS)를 1:9의 비율로 섞은 fixing solution으로 세포를 상온에서 10 분 동안 고정하고 4,6-diamidino-2-phenylindole (DAPI, Sigma) 용액을 이용하여 상온에서 암조건으로 15 분간 염색시켰다. 염색된 세포를 PBS 및 증류수로 세척한 다음 $\mathrm{ab}-$ solute alcohol로 탈수과정을 거친 slide glass 위에 mounting solution을 처리한 후 형광 현미경(Carl Zeiss)을 이용하여 400 배의 배율로 FS 및 FYA 각각 농도에 따른 AGS 세포의 핵 형태변화를 관찰하였다.

\section{Flow cytometry 분석}

FS 및 FYA를 농도별로 처리한 배지에서 배양된 세포를 모 아서 3,000 rpm으로 5 분간 원심 분리하여 상층액을 버리고 세포들만 모은 후 PBS로 충분히 세척 후 CycleTEST Plus DNA Reagent Kit (Becton Dickinson, San Jose, CA, USA)를 사용하여 고정 및 propidium iodide (PI) 염색을 하여 $4^{\circ} \mathrm{C}$, 암실에서 30 분 동안 반응을 시켰다. 염색된 세포를 $35-\mathrm{mm}$ mesh를 이용하여 단일세포로 분리한 후 FACSCalibur (Becton Dickinson)를 이용하여 형광반응에 따른 Cellular DNA content 및 histogram을 Cell Quest software 및 ModiFit 
LT (Becton Dickinson) 프로그램을 이용하여 분석하였다

Reverse transcription-polymerase chain reaction (RT-PCR) 분석

상기한 조건에서 배양된 AGS 세포를 회수하여 PBS로 세척 하고, TRIzol reagent (Invitrogen Co., Carlsbad, CA, USA)를 $4^{\circ} \mathrm{C}$ 에서 1 시간 동안 처리하여 total $\mathrm{RNA}$ 를 분리하였다. 분리 된 RNA를 정량한 후, 각각의 primer (Table 1), DEPC water 그리고 ONE-STEP RT-PCR PreMix Kit (Intron, Korea)를 넣 고 Mastercycler gradient (Eppendorf, Hamburg, Germany) 를 이용하여 증폭하였다. 각 $\mathrm{PCR}$ 산물들의 양적 차이를 확인 하기 위하여 1X TAE buffer로 1\% agarose gel을 만들고 well 당 각각의 primer에 해당하는 PCR 산물에 DNA gel loading solution을 섞어서 loading 한 후 $50 \mathrm{~V}$ 에서 전기영동을 행하였 다. 전기영동으로 $\mathrm{DNA}$ 분리가 끝난 gel을 $\mathrm{EtBr}$ 을 이용하여 염색한 후 UV하에서 확인하고 Picture works' photo enhancer를 이용하여 사진 촬영을 하였다. 이 때 housekeeping 유전자인 glyceraldehyde-3-phosphate dehydrogenase (GAPDH) 유전자를 internal control로 사용하였다.

단백질의 분리, 전기영동 및 Western blotting 위와 동일한 조건으로 FS 및 FYA를 처리한 배지에서 자란
준비된 세포들을 모은 후 PBS로 씻어내고, 적당량의 lysis buffer [25 mM Tris-Cl (pH 7.5), $250 \mathrm{mM} \mathrm{NaCl}, 5 \mathrm{mM}$ EDTA, $1 \%$ NP-40, $1 \mathrm{mM}$ phenylmethylsulfonyfluoride (PMSF), 5 $\mathrm{mM}$ dithiothreitol (DTT)]를 첨가하여 $4^{\circ} \mathrm{C}$ 에서 1 시간 반응시 킨 후, $14,000 \mathrm{rpm}$ 으로 30 분간 원심분리하여 그 상층액을 취 하였다. 상층액의 단백질 농도를 Bio-Rad 단백질 정량시약 (Bio-Rad, Hercules, CA, USA)을 사용하여 사용방법에 따라 정 량한 다음 동량의 Laemmli sample buffer (Bio-Rad)를 섞어 서 sample을 만들었다. 이렇게 만든 동량의 단백질을 sodium dodecyl sulphate (SDS)-polyacrylamide gel을 이용하여 전기 영동으로 분리하였다. 분리된 단백질을 함유한 acrylamide gel을 nitrocellulose membrane (Schleicher and Schuell, Keene, $\mathrm{NH}, \mathrm{USA})$ 으로 전이시킨 후, 비특이적인 단백질과의 결합을 막기 위해 $5 \%$ skim milk를 함유한 PBS-T $(0.1 \%$ Tween 20 in PBS)를 일정시간 처리하였다. 처리된 membrane에 1차 항체를 $4^{\circ} \mathrm{C}$ 에서 overnight 시킨 후 PBS-T로 세척하고 처리된 1 차 항체에 맞는 2 차 항체를 사용하여 상온에서 1 시간 정도 반응 시켰다. 다시 PBS-T로 세척하고 enhanced cheiluminoscence (ECL) 용액(Amersham Life Science Corp., Arlignton Heights, IL, USA)을 적용시킨 다음 암실에서 X-ray film에 감광시켜 특정단백질의 양을 분석하였다. 본 실험에 사용된 1 차 항체들은 Santa Cruz Biotechnology Inc.에서 구입하였으

Table 1. Sequences of primers used for RT-PCR

\begin{tabular}{|c|c|c|}
\hline Primer & & Sequence \\
\hline \multirow{2}{*}{ Bax } & Sense & 5'ATGGACGGGTCCGGGGAG-3' \\
\hline & Anti-sense & 5'-TCAGCCCATCTTCTTCCA-3' \\
\hline \multirow{2}{*}{ Bcl-2 } & Sense & 5'-CAGCTGCACCTGACG-3' \\
\hline & Anti-sense & 5'-GCTGGGTAGGTGCAT-3' \\
\hline \multirow{2}{*}{ CIAP-1 } & Sense & 5'-TGAGCATGVAGACACATGC-3' \\
\hline & Anti-sense & 5'-TGACGGATGAACTCCTGTCC-3' \\
\hline \multirow{2}{*}{ CIAP-2 } & Sense & 5'-CAGAATTGGCAAGAGCTGG-3' \\
\hline & Anti-sense & 5'-CACTTGCAAGCTGCTCAGG-3' \\
\hline \multirow{2}{*}{ XIAP } & Sense & 5'-GAAGACCCTTGGGAACAACA-3' \\
\hline & Anti-sense & 5'-CGCCTTAGCTGCTCTCTTCAGT-3 \\
\hline \multirow{2}{*}{ DR4 } & Sense & 5'-CAGAACGTCCTGCAGCCTGTAAC-3' \\
\hline & Anti-sense & 5’-ATGTCCATTGCCTGATTCTTTGTG-3 \\
\hline \multirow{2}{*}{ DR5 } & Sense & 5'-GGGAAGAAGATTCTCCTGAGATGTG-3' \\
\hline & Anti-sense & 5'-ACATTGTCCTCAGCCCCAGGTCG-3' \\
\hline \multirow{2}{*}{ Fas } & Sense & 5'-TCTAACTTGGGGTGGCTTTGTCTTC-3' \\
\hline & Anti-sense & 5'-CTGTCATACGCTTTCTTTCCAT-3' \\
\hline \multirow{2}{*}{ FasL } & Sense & 5'-CCATTGGGCCTGGGGATGTTTCA-3' \\
\hline & Anti-sense & 5'-AGCCCAGTTTCATTGATCACAAGG-3' \\
\hline \multirow{2}{*}{ TRAIL } & Sense & 5'-ATGGCTATGATGGAGTCCAG-3' \\
\hline & Anti-sense & 5'-TTGTCCTGCATCTGCTTCAGC-3' \\
\hline \multirow{2}{*}{ GAPDH } & Sense & 5'-CGGAGTCAACGGATTTGGTCGTAT-3' \\
\hline & Anti-sense & 5'-AGCCTTCTCCATGGTGGTGAAGAC-3' \\
\hline
\end{tabular}


며, PBS-T에 약 1:500으로 희석하여 사용하였다. 또한, immunoblotting을 위해 2 차 항체로 사용된 peroxidase-labeled donkey anti-rabbit immunoglobulin 및 peroxidase-labeled sheep anti-mouse immunoglobulin은 Amersham Life Science Corp.에서 구입하였다.

\section{결 과}

FS 및 FYA에 의한 AGS 세포의 증식 억제 및 세포의 형 태적 변형

FS 및 FYA가 인체 위암세포 AGS의 세포 증식에 미치는 영향을 알아보기 위하여 FS 및 FYA를 농도별로 처리하여 48 시간 배양한 다음 MTT assay를 실시하였다. 그 결과 FS 및 FYA의 처리 농도가 증가함에 따라 AGS 세포의 증식을 억제되었음을 Fig. 1에서 확인할 수 있었고, 그 효과는 FS보 다 FYA가 더 높게 나타났다. 이러한 암세포의 증식억제 현 상이 세포의 형태에는 어떠한 영향을 미치는지를 알아보기 위해 각각을 농도별로 처리하여 48 시간 동안 배양한 후 도 립현미경을 통하여 세포의 모습을 관찰하였다. 그 결과 FS 및 FYA를 처리하지 않은 세포와 비교하였을 때 FS 및 FYA 를 처리한 세포의 밀도는 농도의존적으로 감소하였고, 세포 의 모양 또한 불규칙적으로 변화된 것을 확인할 수 있었다 (Fig. 2A).

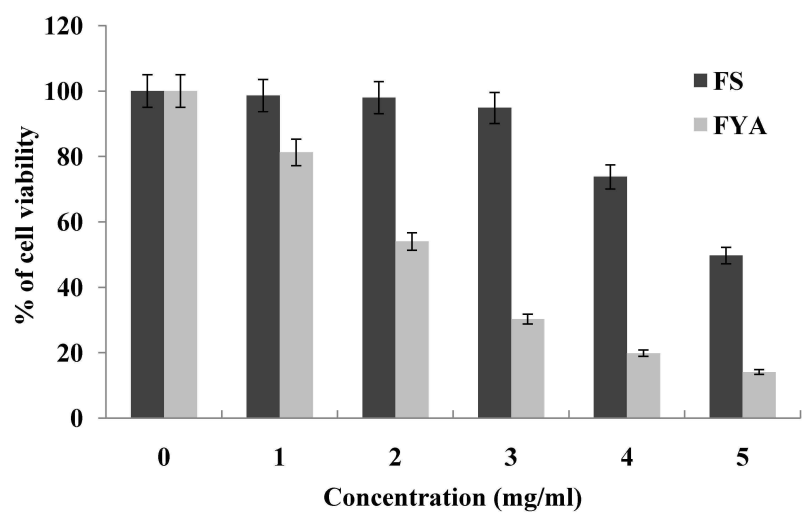

Fig. 1. Effects of ethanol extracts of fermented beans on the cell viability in AGS human gastric cancer cells. The cells were incubated with the indicated concentrations of fermented soybean (FS) and yellow agabean (FYA) for 48 hr. The rates of cell viability were measured by MTT assay. The data shown are means $\pm S D$ of three independent experiments.

FS 및 FYA 처리에 의한 AGS 세포의 apoptosis 유발

이러한 AGS 세포의 증식억제에 따른 형태적 변형이 apoptosis의 유발과 관계가 있을 것으로 예상 되어 핵산에 특이적 으로 결합하는 DAPI 염색을 실시하여 형광현미경을 통하여 세포핵의 변화를 관찰하였다. 그 결과 Fig. $2 \mathrm{~B}$ 에서와 같이 $\mathrm{FS}$ 및 FYA를 처리하지 않은 배지에서 배양된 세포의 경우에는

A)

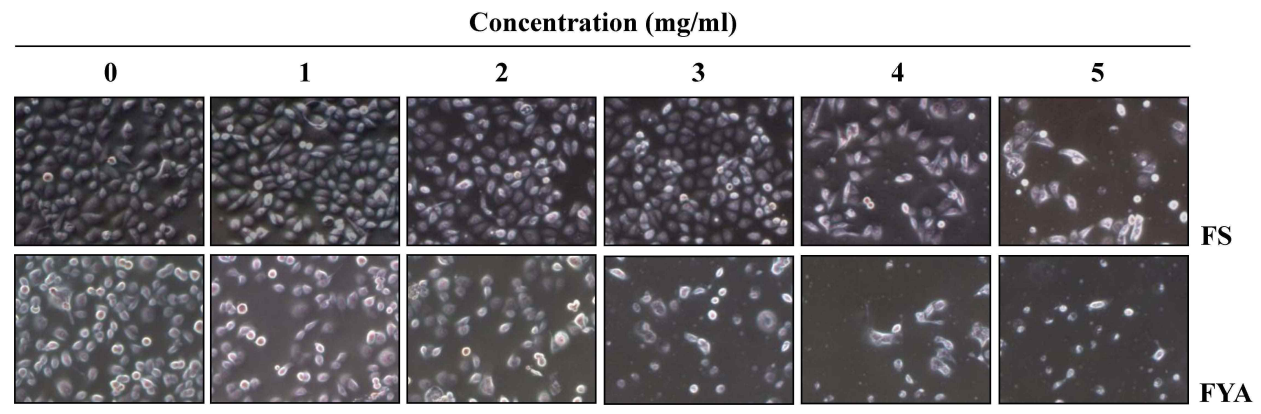

B)

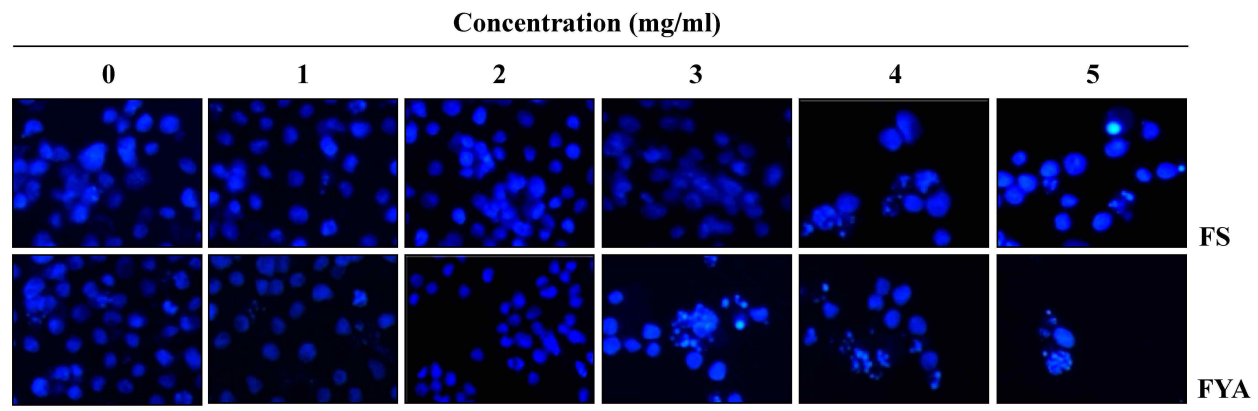

Fig. 2. Morphological changes and induction of chromatin condensation in AGS by FS and FYA. AGS cells were seeded at $1 \times 10^{5} / \mathrm{ml}$ in a 6-well plate and incubated for $24 \mathrm{hr}$. The cells were treated with various concentrations of FS and FYA for $48 \mathrm{hr}$. And then (A) directly photographed by microscopy (Original magnification, $\times 200$ ). (B) Cells were stained with DAPI solution for $10 \mathrm{~min}$ at room temperature, washed with PBS and photographed with a fluorescence microscope using blue filter (Original magnification, $\times 400)$. 
핵의 전체가 고루 염색되는 양상을 보였으나 FS 및 FYA를 처리하였을 때에는 농도 의존적으로 세포의 밀도가 감소하였 고, 농도가 높아질수록 전형적으로 apoptosis가 일어난 세포 에서 관찰되는 apoptotic body의 형성이 증가한 것을 확인하 였다. 따라서 apoptosis 유발 정도를 정량적으로 분석하기 위 하여 DNA flow cytometry를 이용하여 세포주기 중 apoptosis 가 일어난 세포군에 해당하는 sub-G1기의 빈도를 조사한 결 과, FS 및 FYA 처리 농도의 증가에 따라 sub-G1기에 해당하는 세포의 빈도가 증가하는 것을 확인하였다. 이 결과는 특히 $\mathrm{FYA}$ 의 처리군에서의 증가율이 FS보다 높았으며, 최고 농도인 $5 \mathrm{mg} / \mathrm{ml}$ 에서는 apoptotic cell의 함량이 약 $60 \%$ 까지 증가한 것을 알 수 있었다(Fig. 3). 이상의 결과를 통하여 FS 및 FYA 처리에 의한 AGS 위암세포의 증식 억제는 apoptosis 유도와 관련이 있음을 알 수 있었다.

\section{$\mathrm{Bcl}-2$ family의 발현에 미치는 FS 및 FYA의 영향}

FS 및 FYA 처리에 의한 apoptosis 유발하는 과정에 어떠한 유전자들이 관여하는지 확인하기 위해, 먼저 FS 및 FYA를 처 리하였을 때 Bcl-2 family의 발현 변화를 RT-PCR과 Western blotting을 통하여 알아보았다. FS의 경우 처리 농도가 증가하 여도 apoptosis 억제인자인 Bcl-2와 유발인자인 Bax 모두 mRNA 및 단백질 발현 상에서 큰 변화가 없었다. 그러나 FYA 는 번역 수준에서는 큰 변화가 없었지만, 전사 수준에서 농도 가 증가함에 따라 Bcl-2의 발현양이 감소하고, $\mathrm{Bax}$ 의 발현양이 증가하였다(Fig. 4). 이는 앞 선 결과에서 AGS 세포에서 유발 되는 apoptosis에 대한 영향이 FS보다는 FYA의 효과가 더 뛰 어나다는 사실과 어느 정도 연관성이 있는 것이며, FYA에 의 해 유발된 apoptosis는 mitochondrial pathway와 연관이 있을

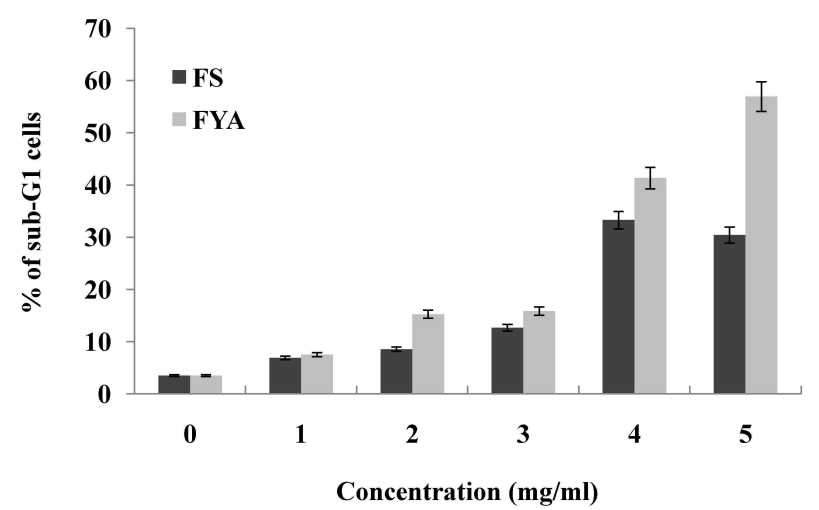

Fig. 3. Apoptosis induction of AGS cells by FS and FYA in AGS cells. Cells were treated with the indicated concentrations of FS and FYA for $48 \mathrm{hr}$, then collected and stained with PI for flow cytometry analysis. The percentages of cells with hypodiploid DNA (sub-G1 phase) contents represent the fractions undergoing apoptotic DNA degradation. Data are expressed as mean \pm SD of three independent experiments.

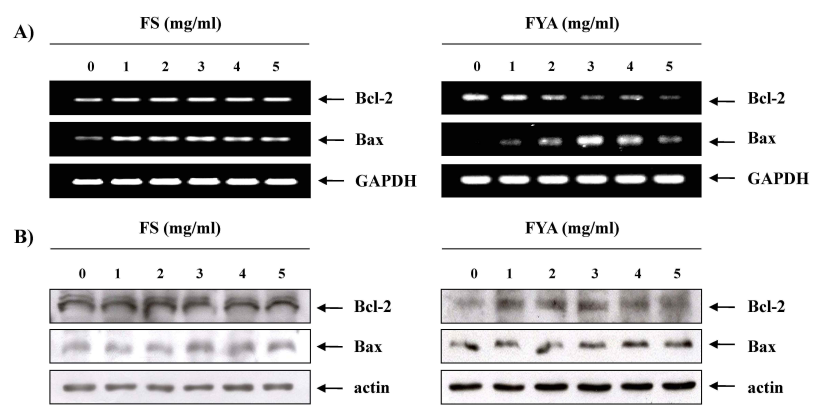

Fig. 4. Effects of FS and FYA treatment on the levels of Bcl-2 family members in AGS cells. (A) After $48 \mathrm{hr}$ incubation with FS and FYA, total RNAs were isolated and reverse-transcribed. The resulting cDNAs were subjected to PCR with the indicated primers, and the reaction products were subjected to electrophoresis in $1 \%$ agarose gel and visualized by EtBr staining. GAPDH was used as an internal control. (B) The cells were lysed and then cellular proteins were separated by 10-13\% SDS-polyacrylamide gels and transferred onto nitrocellulose membranes. The membranes were probed with the indicated antibodies. Proteins were visualized using an ECL detection system. Actin was used as an internal control.

것임을 암시하여 주는 것이다.

IAP family의 발현에 미치는 FS 및 FYA의 영향

Caspase와 직·간접적으로 결합하여 그들의 활성을 차단함 으로서 apoptosis를 억제하는 것으로 알려진 inhibitor of apoptosis protein (IAP) family 인자들이 FS 및 FYA에 의해 유발된 apoptosis에 미치는 영향을 확인하기 위해 mRNA 및 단백질 수준에서 조사하였다. 그 결과 FS 및 FYA를 처리하였 을 때 농도가 증가함에 따라 IAP family 인자의 발현 양이 감소하는 것을 전사 및 번역 수준에서 확인할 수 있었다(Fig. 5). 이 때, IAP family 인자들의 발현 억제에도 FS 보다 FYA에 서 더 뛰어남이 확연하게 드러났다. 이를 통해 FS 및 FYA의 처리에 의한 apoptosis 유발과정에 IAP family의 발현 변화도 어느 정도 관여하였음을 알 수 있었다.

\section{영향}

Death receptor family의 발현에 미치는 FS 및 $\mathrm{FYA}$ 의 다음은 apoptosis의 또 다른 경로인 death receptor (DR) pathway에 관여하는 관련 유전자들의 발현 변화를 조사하였 다. 먼저 FS의 처리 양이 증가함에 따라 DR5, Fas, TRAIL의 발현양이 증가하는 것을 확인하였으며, FYA를 처리하여 확인 한 RT-PCR 및 Western blotting의 결과에서는 DR5, Fas, FasL 의 발현 양도 증가하였음을 알 수 있었다(Fig. 6). 이러한 인자 들의 발현증가는 앞선 결과들과 유사하게 FS 보다 FYA를 처 


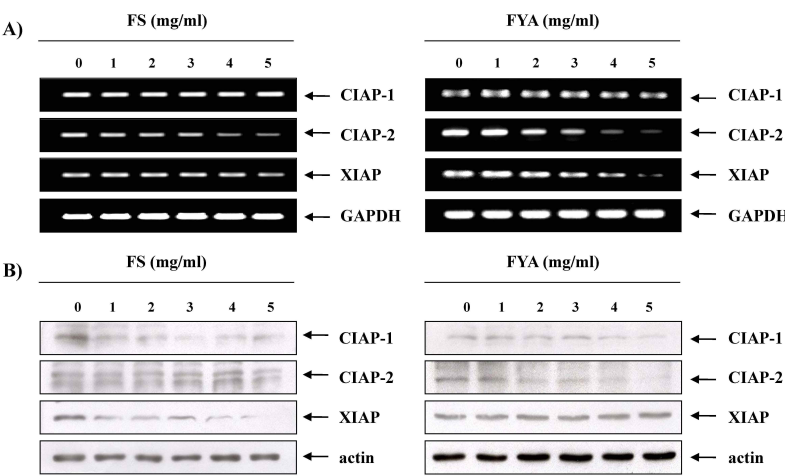

Fig. 5. Effects of FS and FYA treatment on the levels of IAP family members in AGS cells. (A) After $48 \mathrm{hr}$ incubation with FS and FYA, total RNAs were isolated and reverse-transcribed. The resulting cDNAs were subjected to PCR with the indicated primers, and the reaction products were subjected to electrophoresis in 1\% agarose gel and visualized by EtBr staining. GAPDH was used as an internal control. (B) The cells were lysed and then cellular proteins were separated by 10\% SDS-polyacrylamide gels and transferred onto nitrocellulose membranes. The membranes were probed with the indicated antibodies. Proteins were visualized using an ECL detection system. Actin was used as an internal control.

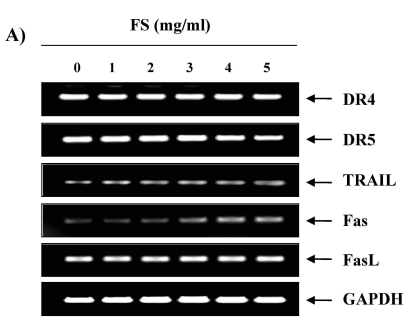

B)

FS (mg/ml)

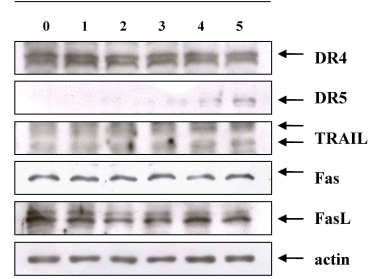

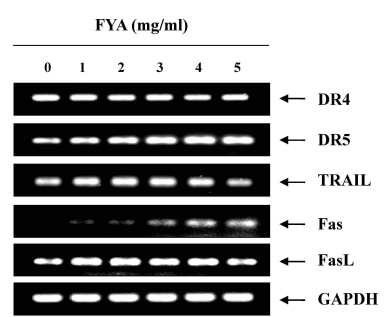

FYA $(\mathrm{mg} / \mathrm{ml})$

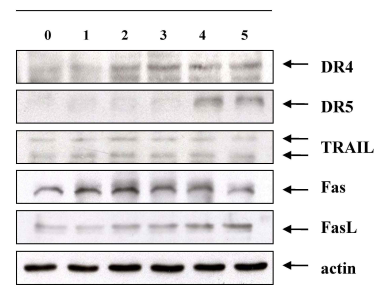

Fig. 6. Effects of FS and FYA treatment on the levels of death-receptor related gene products in AGS cells. (A) After 48 hr incubation with FS and FYA, total RNAs were isolated and reverse-transcribed. The resulting cDNAs were subjected to PCR with the indicated primers, and the reaction products were subjected to electrophoresis in $1 \%$ agarose gel and visualized by EtBr staining. GAPDH was used as an internal control. (B) The cells were lysed and then cellular proteins were separated by $10-13 \%$ SDS-polyacrylamide gels and transferred onto nitrocellulose membranes. The membranes were probed with the indicated antibodies. Proteins were visualized using an ECL detection system. Actin was used as an internal control.

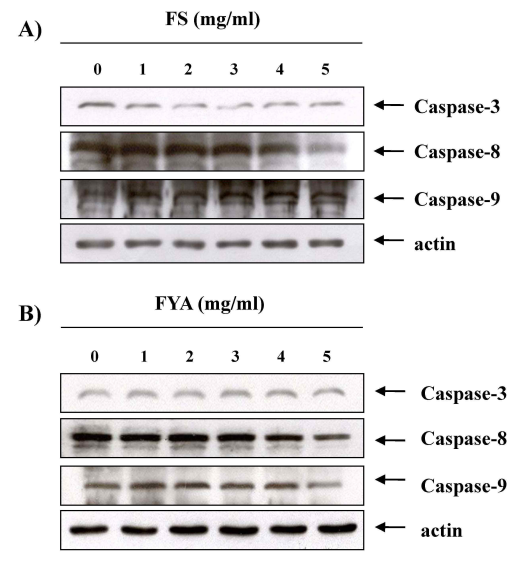

Fig. 7. Effects of FS and FYA treatment on the expression of caspases in AGS cells. After $48 \mathrm{hr}$ incubation with FS (A) and FYA (B), the cells were lysed, and cellular proteins were separated by $8-13 \%$ SDS-polyacrylamide gel and transferred onto nitrocellulose membranes. The membranes were probed with the indicated antibodies. Proteins were visualized using an ECL detection system. Actin was used as an internal control.

리하였을 때 더욱더 확연히 증가하였으며, 이는 AGS 세포 FS 및 FYA에 의한 apoptosis에 death receptor pathway에 연관 된 인자들도 관여할 것임을 의미하는 결과이다.

\section{Caspases의 발현에 미치는 FS 및 FYA의 영향}

Apoptosis 유발에서 가장 핵심적인 역할을 하는 것으로 알 려진 caspase는 크게 apoptosis를 개시하는데 영향을 미치는 initiator caspase와 직접적으로 apoptosis에 관여하는 effector caspase 두 가지로 나눌 수 있다. Initiator caspase에는 caspase-8, -9, -10 및 -12 등이 포함되며, effector caspase에는 caspase-3, -6 및 -7 등이 알려져 있는데, 이 중 caspase-3은 직접적 으로 apoptosis 효과를 가지는 caspase로서, caspase-3의 활성 화는 직접적으로 poly (ADP-ribose) polymerase (PARP)와 같 은 표적 단백질의 단편화에 관여하는 것으로 알려져 있다. 따 라서 apoptosis 유발에 가장 핵심적인 역할을 하는 caspases의 활성에 FS 및 FYA가 미치는 영향을 알아본 결과, Fig. 7에 나타 낸 바와 같이 FS 및 FYA를 처리하였을 때 처리 농도 의존적으 로 caspase-3, -8 및 -9의 비활성 단백질 발현이 감소하는 것을 확인하였다.

\section{고 찰}

본 연구에서는 AGS 인체위암세포에서 발효시킨 콩의 추 출물에 의한 증식억제가 apoptosis 유발에 의한 것인지를 조사하였다. 선행 연구에서 발효시킨 콩의 성분을 정량화한 결과, 총 페놀, 단백질 및 당의 함량이 대두를 발효시킨 FS 보다 노란 아가콩의 발효물인 FYA에서 높은 것을 확인하였 
다[14]. 이를 통해 AGS 인체위암세포에 유발되는 apoptosis 에 페놀, 단백질 및 당이 큰 역할을 한다 유추하였고, 이러 한 효과는 FS보다 FYA에서 더욱 더 뛰어날 것이란 가정을 하였다. 이를 확인하기 위해 먼저 MTT assay를 수행하였는 데, 이는 대사과정이 정상적인 세포가 미토콘드리아의 탈수 소효소 작용에 의하여 노란색의 수용성 MTT tetrazolium을 자주색을 띠는 비수용성의 MTT formazan crystal로 환원되 는 원리를 이용하는 것으로, 그 결과는 Fig. 1과 같이 48 시 간 동안 FS 및 FYA를 처리하였을 때 처리 농도가 증가할수 록 암세포의 증식이 현저하게 억제되는 것을 확인할 수 있 었다. 특히 FS보다 FYA의 효과가 큰 것을 확인하였으며, 이 러한 증식 억제 현상이 세포의 형태에도 변화를 가져올 것 이라 판단하여 현미경으로 관찰하였을 때, 농도 의존적으로 세포의 밀도가 감소하며 불규칙적인 모양으로 변하는 것을 확인하였다(Fig. 2A). 이러한 세포의 증식 억제 및 형태적 변형이 apoptosis의 유발과 밀접한 관련이 있을 것임을 확 인하기 위하여, 핵산에 특이적으로 결합하는 DAPI 염색 후 형광현미경으로 관찰한 결과 Fig. $2 \mathrm{~B}$ 에서와 같이 FS와 FYA 를 처리함에 따라 점차적으로 세포의 밀도가 감소하였고 전 형적으로 apoptosis가 일어난 세포에서 관찰되는 chromatin condensation에 의한 apoptotic body의 형성을 관찰 할 수 있었으며 이러한 현상은 $\mathrm{FS}$ 에 비해 FYA의 고농도 처리군에 서 매우 증가되었다. FS 및 FYA의 처리에 따라 apoptosis가 유발된 정도를 정량적으로 분석하기 위하여 DNA flow cytometry를 이용하여 세포주기 중 apoptosis가 일어난 집단 인 sub-G1기의 빈도를 조사하였다. 그 결과, Fig. 3에서 알 수 있듯이 FS 및 FYA 처리 농도의 증가에 따라 sub-G1기의 세포 빈도가 점차 증가하였는데, 특히 FYA의 처리군에서의 증가율이 FS보다 높았으며, 고농도인 $5 \mathrm{mg} / \mathrm{ml}$ 는 대조군에 비하여 약 60 배 가까이 증가한 것으로 나타났다. 이상의 결 과를 통하여 FS 및 FYA에 의해 일어나는 AGS 인체위암세 포의 증식억제 및 형태적 변화는 apoptosis와 밀접한 연관 성이 있음을 알 수 있었다.

Apoptosis는 death receptor 관련 인자들, Bcl-2 및 IAP family 인자들, 그리고 caspases 등의 유전자들에 의해 조절되 며, 크게 intrinsic 및 extrinsic 2 가지의 경로를 통하여 일어난 다[4,5,9,13,19,24,31]. Mitochodrial pathway라고도 불리우는 intrinsic pathway는 mitochondria 외막에 존재하는 $\mathrm{Bcl}-2$ family가 중요한 역할을 한다[5,13,19,24,31]. Bcl-2 family는 $\mathrm{Bax}, \mathrm{Bak}, \mathrm{Bad}$ 및 Bid 등 apoptosis를 유발하는 인자와 Bcl-2, $\mathrm{Bcl}-\mathrm{xL}$ 등 apoptosis를 억제하는 인자로 나뉘어지는데, 이들은 dimer 상태로 결합되어 mitochondria 외막에서 균형을 이루 어 존재하고 있다. 하지만 다양한 외부 자극을 받게 되면 mitochondria의 막 전위의 변화가 유발되고 균형이 깨어져서 mitochondria 내에 존재하는 cytochrome $c$ 와 같은 여러 apop- tosis 유발 인자들이 세포질로 방출된다. 방출된 cytochrome $c$ 는 apoptotic protease activating factor (apaf)- 1 과 caspase- 9 과 함께 세포질에서 apoptosome 복합체를 형성하는데, 이 apoptosome은 비활성 상태로 존재하고 있는 caspase-3를 활 성화시키게 된다 $[5,8,9,10,13,24,31,32]$. 이러한 intrinsic pathway 과정에서 FS 및 FYA의 처리가 Bcl-2 family의 발현에 변화를 주어 apoptosis를 유발시키는지 알아보기 위해 RT-PCR과 Western blotting을 통하여 mRNA 및 단백질 수준 에서 확인하였다. 그 결과, FS의 경우에는 Bcl-2 family의 발현 이 대조군과 비교해 미약한 변화를 보였으나, FYA는 단백질 수준에서는 큰 변화가 없었으나, 전사 수분에서는 처리 농도 가 증가함에 따라 $\mathrm{Bcl}-2$ 의 발현양이 감소하고, $\mathrm{Bax}$ 의 발현양이 증가하였다(Fig. 4). 한편, apoptosis 조절에서 caspase와 직접 적으로 결합하여 활성을 억제하는 것으로 알려진 IAP family $[7,23]$ 에 속하는 인자들 또한 FS 및 FYA의 처리농도가 증가함 에 따라 $\mathrm{mRNA}$ 상에서나 단백질 수준에서의 발현이 억제되는 것을 확인함으로써 IAP family 인자들 또한 관여를 한다는 사실을 확인하였다(Fig. 5).

한편, 또 다른 경로로 알려진 extrinsic pathway는 mitochondria 비의존적인 apoptosis 과정으로 tumor necrosis factor (TNF) family의 death receptor들의 활성에 의해 야기 되어 death receptor pathway라고도 한다 $[4,5,13,24,28]$. 세포 막에 존재하는 DR4, DR5나 TNF receptor super family에 속 하는 Fas, TNFR-1에 각각의 apoptotic ligand인 TRAIL, FasL, TNF- $a$ 가 결합하게 되면 Fas-associated with death domain protein (FADD) 또는 TNFRSF1A-associated via death domain (TRADD) 및 procaspase-8이 death-inducing signaling complex (DISC)를 형성하게 되어 caspase-8의 활 성화에 의한 caspases cascade에 의하여 apoptosis를 유발하 게 된다 $[3,24,28,29,30]$. 따라서 FS 및 FYA를 처리하였을 때 death receptor에 속하는 유전자들의 발현 변화를 살펴본 결 과, $\mathrm{FS}$ 를 처리한 경우, 처리된 $\mathrm{FS}$ 의 양이 증가함에 따라 $\mathrm{DR} 5$, Fas 및 TRAIL의 발현양이 증가하는 것을 확인하였으 며, FYA를 처리한 경우에는 DR5, Fas 및 FasL의 발현양이 증가하였다(Fig. 6). 이러한 인자들의 발현 증가는 앞선 결과 들과 유사하게 FS보다 FYA를 처리하였을 때 더욱 더 증가함 을 알 수 있었다. 이로 인체 위암세포인 AGS에서 FS 및 FYA 에 의한 apoptosis에 death receptor pathway에 연관된 인자 들이 관여할 것이라는 것을 유추할 수 있었고, 이상의 결과 를 통하여 FS 및 FYA 처리에 의한 apoptosis 유발은 death receptor pathway에 관여하는 death receptor 관련 유전자의 발현 증가와 mitochondrial pathway에 관여하는 Bcl-2 family의 pro-apoptosis 인자의 발현 증가 및 anti-apoptosis 인자 의 발현 억제, 그리고 IAP family의 억제에 의해 이루어지는 것을 확인하였다. 
Apoptosis 유발에 결정적인 역할을 하는 것으로 알려진 caspase들은 cysteine protease로 알려져 있다. 일반적으로 비 활성 전구체 상태로 존재하지만, apoptosis 신호를 받게 되면 기질에 특이적으로 가지고 있는 aspartate 잔기를 쪼개어 apoptosis 과정에 효과적인 형태로 모양을 바꾸는 가수분해과 정을 겪으며 활성을 가지게 된다. Caspase는 크게 caspase-2, $-8,-9$ 및 -10 과 같은 class I 이나 caspase-3, -6 그리고 -7과 같은 class II 두 가지로 나눌 수 있다. Class I 에 속하는 caspase들은 특이적인 분자들과 상호작용하게 되어 신호적 복합 체로 연결되고, 이러한 다양한 신호 전달을 통해 class $\Pi$ 에 속하는 caspase들을 활성화 시켜 apoptosis가 일어나는 동안 에 class II의 caspase들이 세포질에 존재하는 수 백 개의 caspase 표적 단백질의 분해를 유발하게 된다 $[5,13,24]$. 많은 선행 연구에서 caspases의 활성화가 apoptosis의 유발에 대한 증거 가 될 수 있다고 보고되어 있으므로, 본 연구에서는 AGS 세포 에서 caspases의 발현에 미치는 FS 및 FYA의 영향을 조사하였 다. Western blotting을 통하여 caspase의 발현 변화를 관찰한 결과, Fig. 7에서 볼 수 있듯이 FS 및 FYA를 처리하였을 때 caspase-3, -8 및 -9 모두 비활성형인 proform이 감소하였음을 확인할 수 있었다.

이상의 결과에서 FS 및 FYA를 인체 위암세포인 AGS에 처 리하였을 경우 농도 의존적으로 세포의 증식을 강하게 억제하 였고, 이러한 세포 증식억제는 apoptosis 유도와 관련이 있음 을 확인하였다. 이러한 apoptosis는 세포 표면에 존재하는 Fas 에 FasL이 결합하여 일어나는 death receptor pathway 또는 pro-apoptosis 인자인 Bax의 증가와 anti-apoptosis 인자인 $\mathrm{Bcl}-2$ 의 감소에 의해 일어나는 mitochondrial pathway를 통하 여 유발될 것이라 유추된다. 특히 이러한 결과는 FS보다 FYA 처리군에서 더욱더 탁월한 효과를 가지는 것으로 보아, 노란 아가콩이 효과적인 항암제로서의 가능성을 가지는 것을 제시 하며, 이는 노란아가콩에 대한 지속적인 연구가 필요할 것이 라 사료된다.

\section{감사의 글}

본 논문은 농림부 농림기술개발사업의 지원(307003-031-HD140)에 의하여 이루어진 결과의 일부입니다.

\section{References}

1. Baek, J. G., S. M. Shim, D. Y. Kwon, H. K. Choi, C. H. Lee, and Y. S. Kim. 2010. Metabolite profiling of Cheonggukjang, a fermented soybean paste, inoculated with various Bacillus strains during fermentation. Biosci. Biotechnol. Biochem 74, 1860-1868.

2. Blay, M., A. E. Espinel, M. A. Delgado, I. Baiges, C. Bladé,
L. Arola, and J. Salvadó. 2010. Isoflavone effect on gene expression profile and biomarkers of inflammation. J. Pharm Biomed Anal. 51, 382-390.

3. Carlisi, D., M. Lauricella, A. D'Anneo, S. Emanuele, L. Angileri, P. Di Fazio, A. Santulli, R. Vento, and G. Tesoriere. 2009. The histone deacetylase inhibitor suberoylanilide hydroxamic acid sensitises human hepatocellular carcinoma cells to TRAIL-induced apoptosis by TRAIL-DISC activation. Eur. J. Cancer 45, 2425-2438.

4. Chen, S., L. Fu, S. M. Raja, P. Yue, F. R. Khuri, and S. Y. Sun. 2010. Dissecting the roles of DR4, DR5 and c-FLIP in the regulation of geranylgeranyltransferase I inhibitionmediated augmentation of TRAIL-induced apoptosis. Mol. Cancer 9, 23-37.

5. Colussi, P. A. and S. Kumar. 1999. Targeted disruption of caspase genes in mice: what they tell us about the functions of individual caspases in apoptosis. Immunol. Cell Biol. 77, 58-63.

6. Eom, S. M., B. Y. Jung, and H. I. Oh. 2009. Changes in chemical components of Cheonggukjang prepared with germinated soybeans during fermentation. Appl. Biol. Chem 52, 133-141.

7. Foster, F. M., T. W. Owens, J. Tanianis-Hughes, R. B. Clarke, K. Brennan, N. J. Bundred, and C. H. Streuli. 2009. Targeting inhibitor of apoptosis proteins in combination with ErbB antagonists in breast cancer. Breast Cancer Res. 11, R41-53.

8. He, W., M. F. Zhang, J. Ye, T. T. Jiang, X. Fang, and Y. Song. 2010. Cordycepin induces apoptosis by enhancing JNK and p38 kinase activity and increasing the protein expression of Bcl-2 pro-apoptotic molecules. J. Zhejiang Univ. Sci. B. 11, 654-660.

9. Hsu, H. F., J. Y. Houng, C. F. Kuo, N. Tsao, and Y. C. Wu. 2008. Glossogin, a novel phenylpropanoid from Glossogyne tenuifolia, induced apoptosis in A549 lung cancer cells. Food Chem Toxicol. 46, 3785-3791.

10. Huang, J., L. Wu, S. Tashiro, S. Onodera, and T. Ikejima. 2008. Reactive oxygen species mediate oridonin-induced HepG2 apoptosis through p53, MAPK, and mitochondrial signaling pathways. J. Pharmacol. Sci. 107, 370-379.

11. Kada, S., M. Yabusaki, T. Kaga, H. Ashida, and K. Yoshida. 2008. Identification of two major ammonia-releasing reactions involved in secondary natto fermentation. Biosci. Biotechnol. Biochem 72, 1869-1876.

12. Kim, B. M., Y. J. Choi, Y. Han, Y. S. Yun, and S. H. Hong. 2009. N,N-dimethyl phytosphingosine inducescaspase-8dependent cytochrome $\mathrm{c}$ release and apoptosis through ROS generation in human leukemia cells. Toxicol. Appl. Pharmacol. 239, 87-97.

13. Kim, G. M., A. R. Lee, K. W. Lee, J. Y. Park, J. Chun, J. Cha, Y. S. Song, and J. H. Kim. 2009. Characterization of a $27 \mathrm{kDa}$ fibrinolytic enzyme from Bacillus amyloliquefaciens CH51 isolated from cheonggukjang. J. Microbiol. Biotechnol. 19, 997-1004.

14. Kim, S. R., M. J. Kim, H. H. Lee, M. J. Seo, B. W. Kang, W. H. Joo, J. U. Park, J. Rhu, Y. H. Hwang, and Y. K Jeong. 2010. Fibrinolytic activity and antioxidant effects of the new- 
ly develop agabean fermented of product produced by Bacillus sp. J. Life Sci. 20, 1711-1717.

15. Ku, K. M., M. G. Kim, M. J. Hong, Y. S. Jeong, J. S. Kim, I. J. Lee, D. H. Shin, Y. H. Hwang, and Y. H. Kang. 2008. Antioxidant and QR inductive activities of novel functional soybean 'Agakong3'. Food Sci. Biotechnol. 18, 624-629.

16. Lee, M. S., E. Y. Cha, P. T. Thuong, J. Y. Kim, M. S. Ahn, and J. Y. Sul. 2010. Down-regulation of human epidermal growth factor receptor $2 /$ neu oncogene by corosolic acid induces cell cycle arrest and apoptosis in NCI-N87 human gastric cancer cells. Biol. Pharm Bull. 33, 931-937.

17. Li, Y., L. Liu, L. G. Andrews, and T. O. Tollefsbol. 2009. Genistein depletes telomerase activity through cross-talk between genetic and epigenetic mechanisms. Int. J. Cancer 125, 286-296.

18. Li, N., L. L. Fan, G. P. Sun, X. A. Wan, Z. G. Wang, Q. $\mathrm{Wu}$, and H. Wang. 2010. Paeonol inhibits tumor growth in gastric cancer in vitro and in vivo. World J. Gastroenterol. 16, 4483-4490.

19. Moon, D. O., M. O. Kim, Y. H. Choi, N. D. Kim, J. H. Chang, and G. Y. Kim. 2008. Bcl-2 overexpression attenuates SP600125-induced apoptosis in human leukemia U937 cells. Cancer Lett. 264, 316-325.

20. Nagata, C. 2010. Factors to consider in the association between soy isoflavone intake and breast cancer risk. J. Epidemiol. 20, 83-89.

21. Nishito, Y., Y. Osana, T. Hachiya, K. Popendorf, A. Toyoda, A. Fujiyama, M. Itaya, and Y. Sakakibara. 2010. Whole genome assembly of a natto production strain Bacillus subtilis natto from very short read data. BMC Genomics 11, 243-254.

22. Omura, K., M. Hitosugi, X. Zhu, M. Ikeda, H. Maeda, and S. Tokudome. 2005. A newly derived protein from Bacillus subtilis natto with both antithrombotic and fibrinolytic effects. J. Pharmacol. Sci. 99, 247-251.

23. Owens, T. W., F. M. Foster, J. Tanianis-Hughes, J. Y. Cheung, L. Brackenbury, and C. H. Streuli. 2010. Analysis of inhibitor of apoptosis protein family expression during mammary gland development. BMC Dev. Biol. 10, 71-81.

24. Park, C., S. K. Hyun, W. J. Shin, K. T. Chung, B. T. Choi, H. J. Kwon, H. J. Hwang, B. W. Kim, D. I. Park, W. H. Lee, and Y. H. Choi. 2009. Esculetin induces apoptosis through caspase-3 activation in human leukemia U937 cells. J. Life Sci. 19, 249-255.

25. Park, S. I. 2006. Preparation of natto (unripe chungkukjang) using small soybeans and bacillus subtilis KCCM 11315. Korean J. Culinary Res. 12, 223-235.

26. Phommalth, S., Y. S. Jeong, Y. H. Kim, K. H. Dhakal, and Y. H. Hwang. 2008. Effects of light treatment on isoflavone content of germinated soybean seeds. J. Agric. Food Chem 56, 10123-10128.

27. Phommalth, S., Y. S. Jeong, Y. H. Kim, and Y. H. Hwang. Isoflavone composition within each structural part of soybean seeds and sprouts. J. Crop Sci. Biotech 11, 57-62.

28. Seo, S. B., J. H. Hur, M. J. Kim, J. W. Lee, H. B. Kim, J. H. Bae, D. W. Kim, C, D, Kang, and S. H. Kim. 2010. TRAIL sensitize MDR cells to MDR-related drugs by down-regulation of P-glycoprotein through inhibition of DNA-PKcs/Akt/GSK-3beta pathway and activation of caspases. Mol. Cancer 9, 199-213.

29. Shankar, S., Q. Chen, S. Ganapathy, K. P. Singh, and R. K. Srivastava. 2008. Diallyl trisulfide increases the effectiveness of TRAIL and inhibits prostate cancer growth in an orthotopic model: molecular mechanisms. Mol. Cancer. Ther. 7, 2328-2338.

30. Wang, C., T. Chen, N. Zhang, M. Yang, B. Li, X. Lü, X. Cao, and C. Ling. 2009. Melittin, a major component of bee venom, sensitizes human hepatocellular carcinoma cells to tumor necrosis factor-related apoptosis-inducing ligand (TRAIL)-induced apoptosis by activating CaMKII-TAK1$\mathrm{JNK} / \mathrm{p} 38$ and inhibiting IkappaBalpha kinase-NFkappaB. J. Biol. Chem 284, 3804-3813.

31. Yeruva, L., K. J. Pierre, A. Elegbede, R. C. Wang, and S. W. Carper. 2007. Perillyl alcohol and perillic acid induced cell cycle arrest and apoptosis in non small cell lung cancer cells. Cancer Lett. 257, 216-226.

32. Ying, M., C. Tu, H. Ying, Y. Hu, Q. He, and B. Yang. 2008. MSFTZ, a flavanone derivative, induces human hepatoma cell apoptosis via a reactive oxygen species- and caspase-dependent mitochondrial pathway. J. Pharmacol. Exp. Ther. 325, 758-765.

33. Zhang, L., Y. H. Hou, K. Wu, J. S. Zhai, and N. Lin. 2010. Proteomic analysis reveals molecular biological details in varioliform gastritis without Helicobacter pylori infection. World J. Gastroenterol. 16, 3664-3673. 


\section{초록 : AGS 인체위암세포에서 발효된 아가콩 추출물에 의한 apoptosis 유도}

김성열 ${ }^{1} \cdot$ 이혜현 ${ }^{1,2} \cdot$ 김민정 $^{1,2} \cdot$ 서민정 $^{2,3} \cdot$ 홍수현 $^{4} \cdot$ 최영현 $^{4} \cdot$ 강병원 $^{1,2} \cdot$ 박정욱 $^{1,2} \cdot$ 주우홍 $^{5} \cdot$ 류은주 $^{6}$. 정영기 ${ }^{1,2,3}$ *

(1동아대학교 생명공학과, ${ }^{2}$ 동아대학교 Medi-Farm 산업화 연구사업단, ${ }^{3}$ 동아대학교 의생명과학과, ${ }^{4}$ 동의대 학교 한의과대학 생화학교실 및 한의학연구소, 대학원 바이오물질제어학과 및 블루바이오 소재개발센터,

${ }^{5}$ 창원대학교 생물학과, ${ }^{6}$ 한서대학교 피부미용학과)

본 연구에서는 대두(FS)와 아가콩의 발효추출물(FYA)의 항암활성 기전을 확인하기 위해 AGS 인체위암세포의 증식에 미치는 영향을 조사하였다. AGS 세포에서 FS 및 FYA 처리로 인하여 암세포의 증식이 처리 농도 의존적 으로 강하게 억제하였고, apoptosis 유발을 의미하는 세포의 전반적인 형태 및 핵의 변형 또한 동반하였다. 또한 세포주기 분석을 통하여 이 현상이 apoptosis 유도에 의한 것임을 확인하였다. AGS 세포에 처리된 FS 및 FYA는 pro-apoptotic factor인 Bax의 발현 증가를 통한 intrinsic pathway나, death receptor 관련 유전자의 발현 증가를 통한 extrinsic pathway를 활성화시키며, 더 나아가서 IAP family인자의 발현 억제 및 caspases의 활성 증가를 일으켜 apoptosis를 유발시키는 것을 유추할 수 있었는데, 이러한 효과들은 FS보다 FYA에서 더욱더 탁월하였다. 이는 향후 아가콩 발효추출물이 항암치료를 위한 적용 가능성이 매우 우수함을 제시하여 주는 결과이다. 